\title{
La detención preventiva en Colombia: Tensiones entre fines constitucionales y derechos fundamentales ${ }^{1}$
}

\author{
Preventive Detention in Colombia: Tensions between Constitutional \\ Purposes and Fundamental Rights
}

\author{
Diana Marcela TRUJILLO VALLEJO² \\ Sergio Orlando SILVA ARROYAVE 3
}

\begin{abstract}
Resumen: Este artículo analiza cómo la aplicación en Colombia de la institución procesal "detención preventiva" limita el derecho fundamental a la libertad en aras de satisfacer fines constitucionalmente válidos, lo que supone una tensión entre estos. Como solución a este conflicto se acudirá a la jurisprudencia de la Corte Constitucional —sentencia C 469 de 2016 - que desarrolla el principio de proporcionalidad. Se concluye que el fin constitucional de protección a la víctima y/o comunidad es el único que se puede considerar válido para imponer la medida, porque protege bienes en concreto y genera una verdadera colisión entre derechos fundamentales.
\end{abstract}

Palabras clave: Derechos fundamentales, Libertad, Fines constitucionales, Principio de proporcionalidad

\begin{abstract}
This article analyses how in Colombia, the implementation of the procedural institution of pre-trial detention constrains the fundamental right of freedom in pursuit of satisfying admissible constitutional ends, which causes tension between those. Therefore, as a solution to this conflict, the jurisprudence of the Colombian Constitutional Court will be resorted - sentence C 469 of 2016 - that develops the proportionality principle. It is concluded that the constitutional end of protection to the victim and the community is the

\footnotetext{
${ }^{1}$ Avance de investigación en el programa de doctorado en Derecho, Universidad de Medellín (Medellín, Colombia).

${ }^{2}$ Estudiante de doctorado en Derecho, Universidad de Medellín (Medellín, Colombia). Abogada de la Universidad Autónoma Latinoamericana (Medellín). Especialista en Derecho Procesal Penal por la misma institución. Magíster en Derecho de la Universidad de Medellín. Correo electrónico: dtrujillo@udem.edu.co

${ }^{3}$ Doctor en Derecho de la Universidad de Medellín (Medellín). Profesor del Tecnológico de Antioquia (Medellín). Correo electrónico: sosilva694@yahoo.com
} 
only one that could be considered valid to impose the measure, because it protects concrete goods, and generates a true collision between fundamental rights.

Keywords: Fundamental Rights, Freedom, Constitutional Ends, Proportionality Principle

\section{Introducción}

El actual sistema penal acusatorio colombiano de naturaleza garantista —Ley 906 de 20044_ cuya base es el respeto a las garantías y derechos constitucionales de los individuos admite dos formas de privar de la libertad a un individuo. Primero, la sentencia condenatoria que sanciona al responsable de la comisión de una conducta punible; y, segundo, medidas de aseguramiento preventivas -algunas privativas de la libertad ${ }^{5} \mathrm{y}$ otras que ofrecen una opción distinta con mayor satisfacción de los derechos fundamentales del imputado - . en conjunto, velan por el cumplimiento de unos fines señalados en la Constitución colombiana y la ley penal. Se han utilizado como instrumento para alcanzar los fines que propone el proceso penal: garantizar la justicia y los derechos de las partes e intervinientes: imputado/víctima7.

La detención preventiva es entendida como la institución procesal que limita la libertad personal del imputado con la finalidad de dar cumplimiento a fines constitucionales consagrados en los artículos 250 del texto superior y 308 del Código de Procedimiento Penal (CPP). Por lo tanto, es un mecanismo utilizado para salvaguardar el proceso penal, garantizar derechos de las víctimas y proteger a la sociedad de la futura comisión de delitos. Asimismo, se considera necesaria para que el Estado satisfaga fines constitucionales: seguridad ciudadana, justicia, sanción de delitos, orden público y convivencia pacífica. Conforme con lo anterior, la Corte Constitucional Colombiana (CCC $)^{8}$ señala que:

Las medidas de aseguramiento tienen una doble naturaleza que plantea relevantes problemas a la hora de proporcionar una justificación aceptable a su existencia. De un lado, son auténticas restricciones de derechos fundamentales; de suyo comportan una privación o reducción en grados más o menos importantes de prerrogativas de carácter constitucional y especialmente de la libertad. [...] El legislador recurre a ellas porque busca preservar también otros bienes

\footnotetext{
${ }^{4}$ Código de Procedimiento Penal, en adelante CPP.

${ }^{5}$ Las medidas privativas de la libertad incluyen la detención preventiva en establecimiento de reclusión y la detención preventiva en la residencia señalada por el imputado. Ley 906 de 2004, artículo 307, literal A.

${ }^{6}$ La libertad, presunción de inocencia, debido proceso, a la defensa y a la dignidad humana. Bieri (2017), p. 13.

7 Urbano (2006), pp. 111-128.

${ }^{8}$ En adelante CCC o la Corte.
} 
importantes, con frecuencia reconducibles también a derechos de otras personas, cuya garantía depende de las limitaciones que esas medidas llevan a cabo ${ }^{9}$.

Dada la doble naturaleza de las medidas de aseguramiento la teoría sostiene que hay una tensión entre los derechos fundamentales del imputado y los de las víctimas/comunidad. Por un lado, víctima y sociedad reclaman del Estado seguridad y ven en la detención preventiva una "respuesta a la alarma social frente al delito" que garantiza condiciones mínimas de seguridad para evitar que sus bienes jurídicos sean lesionados o para cesar la vulneración que se les ha causado $^{10}$. Asimismo, se constituye una aparente contradicción entre los intereses del proceso penal y los derechos del imputado, pues este al gozar aún de la presunción de inocencia ${ }^{11}$ exige que se le respeten sus derechos, los cuales se ven limitados con el fin de dar cumplimiento a fines constitucionales válidos.

De acuerdo con lo anterior, partimos de la pregunta: ¿se opone la detención preventiva a los derechos fundamentales de la ciudadanía colombiana? Nuestra hipótesis sugiere que dicha medida de aseguramiento no necesariamente se opone o anula los derechos fundamentales de los individuos, pues pretende proteger a la víctima, a la sociedad y al proceso penal, pero proponemos que su aplicación sí supone un conflicto, una tensión con los derechos fundamentales del imputado. Por ello, el artículo revisará esta hipótesis al analizar si la aplicación de la detención preventiva en Colombia es conforme con la constitución e identificar la tensión entre fines constitucionales y el derecho fundamental a la libertad. Para resolver esta inquietud se utiliza la metodología de investigación teórica y documental de tipo jurídicodogmático bajo análisis-síntesis aplicado a una exégesis jurisprudencial comparativa ${ }^{12}$.

Se parte de un abordaje teórico para definir qué son los derechos fundamentales $\mathrm{y}$, concretamente, qué es el derecho a la libertad individual. Luego, se caracteriza la naturaleza y alcance de los fines constitucionales consagrados en la Constitución Política de 1991, para estructurar con su definición el núcleo de la tensión que se genera entre los fines válidos y la libertad. Por último, se propone como solución a este conflicto el principio de proporcionalidad, para lo cual se analizará su estructura según los postulados trazados en la Sentencia C 469 de 2016 de la CCC.

\footnotetext{
${ }^{9}$ Corte Constitucional de Colombia, Sentencia C 469 de 2016.

10 Ospina (2015), p. 18.

${ }^{11}$ Camilo Sampedro considera que la detención preventiva resulta inadmisible, en tanto al hacerse un análisis frente al derecho fundamental de presunción de inocencia esta no tendría cabida. Sampedro (2012), pp. 292 y 296.

12 Clavijo, Guerra y Yánez (2014), pp. 48-53; Villabella (2020), p.937; García (2015), pp. 455-457.
} 


\section{Derecho fundamental a la libertad del imputado y fines constitucionales en la detención preventiva: conflictos constitucionales}

La detención preventiva implica principalmente una limitación al derecho fundamental a la libertad personal del individuo, en este caso, representado por el imputado. La doctrina jurídica la define como:

Medida precautoria de índole personal que crea al individuo sobre quien recae, un estado más o menos permanente de privación de su libertad física soportada en un establecimiento público destinado al efecto y que es decretada por el juez competente en el curso de una causa, contra el sindicado como partícipe en la comisión de un delito reprimido con pena privativa de la libertad ${ }^{13}$.

En el sistema interamericano ha sido entendida como "el periodo de privación de libertad de una persona sospechosa de haber cometido un delito, ordenado por una autoridad judicial y previo a una sentencia firme"14, según la Comisión Interamericana de Derechos Humanos en informe elaborado sobre el uso de la prisión preventiva en las Américas los requisitos que debe atender la detención preventiva son los siguiente:

(i) es una medida excepcional; (ii) los fines legítimos y permisibles deben tener carácter procesal, tales como: evitar el peligro de fuga o la obstaculización del proceso;(iii) La existencia de indicios de responsabilidad no constituye razón suficiente para decretarla;(iv) que sea absolutamente necesaria y proporcional, en el sentido de que no existan otros medios menos gravosos para lograr el fin procesal que se persigue y que no se afecte desproporcionadamente la libertad personal; (v) todos los aspectos anteriores requieren una motivación individualizada que no puede tener como sustento presunciones; (vi) debe decretarse por el tiempo estrictamente necesario para cumplir el fin procesal, lo que implica una revisión periódica de los elementos que dieron lugar a su procedencia; (vii) el mantenimiento de la detención preventiva por un plazo irrazonable equivale a adelantar la pena; y (vii) en el caso de niños, niñas y adolescentes los criterios de procedencia de la detención preventiva debe aplicarse con mayor rigurosidad, procurándose un mayor uso de otras medidas cautelares o el juzgamiento en libertad; y cuando sea procedente deberá aplicarse durante el plazo más breve posible ${ }^{15}$.

Por su parte, en el ordenamiento jurídico colombiano el uso de este instrumento debe cumplir los principios legales fijados por el legislador en el artículo 306 y siguientes del CPP, según los cuales esta limitación a un derecho fundamental debe ser excepcional y con fines preventivos, a condición de que su imposición la realice un juez competente en virtud de la reserva judicial ${ }^{16} \mathrm{y}$ del siguiente procedimiento:

${ }^{13}$ Zavaleta (1954), p. 74. Citado en Palacios (2016), p. 41.

${ }^{14}$ Comisión Interamericana de Derechos Humanos (2013), p. 13.

15 Comisión Interamericana de Derechos Humanos (2013), p.8.

${ }^{16}$ Corte Constitucional de Colombia, Sentencia C 469 de 2016. 
La medida de aseguramiento debe ser solicitada — rogada - por la Fiscalía, el artículo 250 de la Constitución faculta al ente investigador para hacerlo con la condición de que aporte elementos de conocimiento que la sustenten. Dicha solicitud se realiza en las audiencias preliminares, legalización de captura - cuando se presente, formulación de imputación, o por parte de la víctima o su apoderado ${ }^{17}$, y debe hacerse ante el juez de control de garantías, quien es el encargado de decretarla o negarla y establecer si a partir de los elementos materiales probatorios y evidencia aportados por la Fiscalía ${ }^{18}$ se puede constituir una inferencia razonable de autoría o participación en la conducta delictiva investigada que amerite la imposición de la medida ${ }^{19}$.

La Fiscalía tiene la obligación de justificar la necesidad y urgencia de privar de la libertad al imputado, basándose en los casos que, según la Ley, permiten la detención —artículo 313 del CPP, modificado por el artículo 60 de la Ley 1453 de 2011, el artículo 7 de la Ley 1826 de 2017 y adicionado por Ley 1908 de 2018 - Sobre los fines de la restricción de la libertad, la normativa expresa:

La libertad personal podrá ser afectada dentro de la actuación cuando sea necesaria para evitar la obstrucción de la justicia, o para asegurar la comparecencia del imputado al proceso, la protección de la comunidad y de las víctimas, o para el cumplimiento de la pena ${ }^{20}$.

Aunque en el texto constitucional las finalidades de la detención se pueden entender como funciones del ente acusador, la ley penal las desarrolla de manera independiente. En este sentido, el artículo 308 y siguientes del CPP se refieren a ellas como "requisitos", que doctrinaria y jurisprudencialmente son definidos como fines constitucionales ${ }^{21}$ de la medida de aseguramiento: Además de las finalidades que consagra el Sistema Interamericano que son: evitar la obstrucción de la justicia; que resulte probable que el imputado no comparezca en el proceso; o que no se cumplirá con la sentencia en el eventual caso que resulte condenatoria, el legislador colombiano adicionó como fines de la medida de aseguramiento: que el imputado constituya un peligro para la comunidad o para la víctima; Estos fines buscan, la protección de

\footnotetext{
${ }^{17}$ Corte Constitucional de Colombia, Sentencia C 456 de 2006.

${ }^{18}$ Algunos doctrinantes han planteado la discusión sobre el rol del juez de garantías en la valoración de la responsabilidad al momento de imponer la medida con base en los medios probatorios que determinan la inferencia razonable de autoría o participación. Así, según Sandoval y Del Villar (2013), p. 154: "aunque nos parece que esta audiencia si entraña un debate sobre la responsabilidad, y su ausencia, pero solo en torno a si hay mérito probatorio para proferir la medida o no". Sorza (2016), p. 50: plantea que, a partir del análisis de la teoría del delito que estudia la estructura de la conducta punible (tipicidad, antijuridicidad y culpabilidad) el juez de control de garantías hace un análisis de responsabilidad penal que le permita concluir la inferencia de autoría o participación de lo contrario sus decisiones serian basadas en una responsabilidad objetiva.

${ }^{19}$ Ley 906 de 2004, artículo 308.

${ }^{20}$ Constitución Política de Colombia,1991, artículo 250; Ley 906 de 2004, artículo 296.

${ }^{21}$ Es preciso aclarar que, con respecto a la terminología utilizada para referirse a las finalidades, se observa una imprecisión. La doctrina se refiere a ellas como "causales, requisitos o fines constitucionales". La Corte Constitucional los denomina como "fines constitucionales". En este trabajo se acoge la terminología utilizada por la Corte Constitucional.
} 
derechos concretos. En el caso de la protección de la víctima se protegen los bienes jurídicos que tutela la ley penal - Ley 599 de 2000-, mientras que la comunidad es protegida contra conductas punibles que generan inseguridad $y$ temor, situaciones amparadas constitucionalmente en los artículos 1 y 2 sobre cuidado de interés general y de convivencia pacífica. La obstrucción al proceso y la no comparecencia protegen aspectos procesales del proceso penal.

Cuando el fiscal solicita una medida de aseguramiento que restringe la libertad del procesado, dicha restricción debe hacerse atendiendo a los criterios de necesidad, adecuación, proporcionalidad y razonabilidad —artículo 295 del CPP—, que no es otra cosa que valerse del principio de proporcionalidad ${ }^{22}$ en aras de satisfacer los fines que se propone. La Corte afirma que la detención preventiva posee una doble naturaleza: de un lado protege los derechos fundamentales y de otro los limita; correlatividad que genera tensiones entre ellos. Para el imputado la aplicación de la detención preventiva significa limitación en sus derechos fundamentales: libertad personal y presunción de inocencia, pues quien se encuentra privado de su libertad aún no ha sido vencido en juicio, es decir, el juez competente no ha proferido sentencia condenatoria que demuestre su culpabilidad y es el Estado en cabeza de la Fiscalía quien tiene la carga de desvirtuar dicha presunción. Para precisar los términos de este conflicto, proponemos definir los conceptos de derechos fundamentales, libertad y fines constitucionales de la detención preventiva.

Luigi Ferrajoli define los derechos fundamentales como aquellos "derechos subjetivos que corresponden universalmente a 'todos' los seres humanos en cuanto dotados del status de personas, de ciudadanos o personas con capacidad de obrar"23. Esta definición propone dos conceptos: "derecho subjetivo" que hace referencia a cualquier "expectativa positiva" — de prestaciones - o negativa - de no sufrir lesiones que se da en favor de un sujeto y se encuentra contemplada en una norma jurídica-; y el status referido a "la condición de un sujeto, prevista asimismo por una norma jurídica positiva, como presupuesto de su idoneidad para ser titular de situaciones jurídicas y/o autor de los actos que son ejercicio de estas"24. También se defiende la teoría del derecho penal mínimo donde "se protejan las garantías y derechos que la democracia

${ }^{22}$ Alexy (2014), p. 45.

${ }^{23}$ Ferrajoli (2007), p. 19.

24 Ídem, p. 19. 
pone en riesgo"25, siendo las garantías la técnica por medio de la cual se tutelan y satisfacen esos derechos 26 .

La Corte define los derechos fundamentales como: "(i) Aquellos derechos respecto de los cuales existe consenso sobre su naturaleza fundamental y (ii) todo derecho que funcionalmente esté dirigido a lograr la dignidad humana y sea traducible en un derecho subjetivo"27. Lo fundamental de un derecho no está determinado por su denominación o ubicación dentro del texto constitucional sino porque es un soporte que garantiza a los individuos materialización de su dignidad 28 .

Lo anterior supone que los derechos fundamentales son de carácter enunciativo, toda vez que están condicionados por la dignidad. La Constitución Política (art. 94), reconoce dicho carácter y afirma que el no reconocimiento de otros derechos no implica su negación; ello abre la posibilidad de reconocer otros derechos y su fundamentalidad en tanto se relacionen con la dignidad ${ }^{29}$. A pesar de su importancia constitucional, un rasgo de los derechos fundamentales es que no tienen un carácter absoluto, lo que implica que pueden ser limitados en aras de garantizar la protección de otros bienes o derechos consignados en el ordenamiento jurídico. En ese orden de ideas, corresponde al legislador establecer en qué términos se hace indispensable la limitación de ciertos derechos fundamentales.

Cabe apuntar que el sistema constitucional colombiano no establece jerarquías entre ellos, sino que defiende como principio de actuación jurídica una armonización que permita mantener una adecuada convivencia social. Por lo tanto, si hay contradicción entre ellos o con respecto a intereses constitucionalmente protegidos de igual valor, esta estructura normativa admite que los "conflictos" puedan ser ponderados, lo que significa que los derechos tendrán peso relativo, es decir, en ciertos casos concretos un derecho podrá ceder frente a otro ${ }^{30}$. La aplicación de una institución como la detención preventiva supone una tensión entre los derechos fundamentales del imputado y los fines constitucionales. En este sentido la detención preventiva limita el derecho fundamental de la libertad.

\footnotetext{
25 Gargarella (2016), p. 68.

${ }^{26}$ Ferrajoli (2016), p. 13.

${ }^{27}$ Corte Constitucional de Colombia, Sentencia T 760 de 2008; y sentencia T 196 de 2014.

${ }^{28}$ Corte Constitucional de Colombia, Sentencia T 571 de 1992.

${ }^{29}$ Corte Constitucional de Colombia, Sentencia, T 905 de 2012.

${ }^{30}$ Corte Constitucional de Colombia, Sentencia, C 475 de 1997.
} 


\subsection{LALIBERTAD}

A partir de la Constitución Política de 1991, Colombia se constituyó como un Estado social de derecho, lo que implica el reconocimiento de unas condiciones mínimas de existencia digna. Por ello cuenta con un texto garantista que reconoce una serie de derechos fundamentales al individuo, entre estos, el derecho a la libertad, a la cual se le ha dado una fundamentación tanto desde su esfera individual como social. La Corte, por ejemplo, le atribuye una triple naturaleza jurídica: como valor, cuando se consagra en el preámbulo de la constitución; como principio, que debe permear toda la acción del Estado —artículo 2 de la constitución-; y como derecho fundamental, en tanto responde a la ausencia de limitaciones a la autonomía del individuo artículo 28 de la constitución-.

Desde la esfera personal o individual se ha entendido la libertad como la posibilidad y el ejercicio positivo de todas las acciones dirigidas a desarrollar las aptitudes y elecciones individuales que no pugnen con los derechos de los demás ni entrañen abuso de los propios, como la proscripción de todo acto de coerción física o moral que interfiera o suprima la autonomía de la persona sojuzgándola, sustituyéndola, oprimiéndola o reduciéndola indebidamente ${ }^{31}$. Es un "presupuesto para la eficacia de los demás derechos" y un "instrumento del ser humano para vivir en sociedad".

La esfera social, por su parte reconoce al individuo desde la convivencia colectiva, ello implica necesariamente la imposición de "obligaciones o deberes jurídicos", circunstancia que posibilita el reconocimiento de la libertad, pero a su vez la limita ${ }^{32}$. La libertad desde su contenido axiológico y social comprende "la proclamación de la singularidad de cada uno, sin entorpecer, el desarrollo vital propio, ni el de los demás”33, o la búsqueda del bien común. Mediante la convivencia digna y la aceptación de las libertades individuales se construye la libertad social. Para la Corte Constitucional, la libertad tiene un contenido axiológico que necesariamente “desprende consecuencias normativas en la interpretación y aplicación" de todo el orden jurídico colombiano y en las actuaciones de sus autoridades, la cuales deben estar encaminadas a la "protección de la vida, honra, bienes y demás derechos libertades" (art. 2 Constitución

${ }^{31}$ Corte Constitucional de Colombia, Sentencia C 774 de 2001.

${ }^{32}$ Corte Constitucional de Colombia, Sentencia SU 747 de 1998.

${ }^{33}$ Corte Constitucional de Colombia, Sentencia C 221 de 1994. 
Política), ya que como lo revelan su preámbulo y el citado artículo, el texto constitucional es por antonomasia libertario, democrático y opuesto a todo autoritarismo ${ }^{34}$.

El régimen constitucional colombiano reconoce que en el individuo se protege el derecho fundamental a la libertad y esto justifica la existencia del Estado y su regulación jurídica ${ }^{35}$, el artículo 28 del texto constitucional consagra como derecho fundamental, la libertad. Por lo tanto, el principio fundante de la legislación colombiana es que sus ciudadanos gocen de la mayor libertad posible de vida e interacción, excepto cuando esta deba restringirse en defensa de la libertad social, y de la voluntad colectiva.

De acuerdo con lo anterior, se establecen unas garantías para la protección de la libertad en caso de su restricción, por lo que el texto superior en sus artículos 28 y 29 consagró derechos al imputado como ser informado sobre los motivos de la detención, ser detenido por motivos previamente definidos por el legislador y en virtud de mandamientos escritos por autoridad judicial competente ${ }^{36}$. A pesar de la importancia constitucional del derecho a la libertad personal y que debe ser la regla general para el individuo, no se puede desconocer que es un derecho susceptible de ser limitado. Así como los derechos fundamentales no son absolutos, sus limitaciones tampoco pueden serlo. Por lo tanto, dicha restricción debe ser temporal:

El legislador, al regular los supuestos en los que opere la restricción del derecho, debe observar criterios de razonabilidad y proporcionalidad que fuera de servir al propósito de justificar adecuadamente una medida tan drástica, contribuyan a mantener inalterado el necesario equilibrio entre las prerrogativas en que consiste el derecho y los límites del mismo ${ }^{37}$.

Para evitar abusos del poder estatal que vulneren gravemente la libertad, estas limitaciones deben darse en el marco del proceso penal, por ejemplo, mediante sanciones impuestas en la sentencia condenatoria y medidas de aseguramiento privativas de la libertad, las cuales solo pueden operar con fines preventivos como los referidos. La detención preventiva implica la limitación a la libertad personal o la imposición de otras obligaciones que garantizan fines legal y constitucionalmente admisibles, lo que significa que se encuentra sometida a un conjunto de límites formales y sustanciales "que funcionan como garantías para la salvaguarda de la dignidad humana y la proscripción del exceso en su utilización”38. Como desarrollo legal del derecho a la libertad, el CPP la establece como un principio y admite su restricción solo "en virtud de un

\footnotetext{
34 “Expresión empleada en la sentencia T 237 de 2004” (Corte Constitucional de Colombia, Sentencia C 879 de 2011 ).

35 Bernal y Montealegre (2013), p. 109.

${ }^{36}$ Corte Constitucional de Colombia, Sentencia C 176 de 2007.

${ }^{37}$ Corte Constitucional de Colombia, Sentencia C 327 de 1997.

${ }^{38}$ Corte Constitucional de Colombia, Sentencia C 469 de 2016.
} 
mandamiento escrito de una autoridad judicial competente, emitido con las formalidades legales y por motivos previamente definidos en la ley". Dentro del artículo se define la medida de aseguramiento como una forma de restringir la libertad del imputado:

El juez de control de garantías, previa solicitud de la Fiscalía General de la Nación ordenará la restricción de la libertad del imputado cuando resulte necesaria para garantizar su comparecencia o la preservación de la prueba o la protección de la comunidad, en especial, de las víctimas. Igualmente, por petición de cualquiera de las partes, en los términos señalados en este código, dispondrá la modificación o revocación de la medida restrictiva si las circunstancias hubieren variado y la convirtieren en irrazonable o desproporcionada ${ }^{39}$.

El artículo 295 del CPP señala las condiciones que “autorizan preventivamente la privación o restricción de la libertad". Dicha medida solo puede aplicarse a quien tiene la calidad de imputado, la cual adquiere luego de la audiencia de formulación de imputación. La detención manifiesta el carácter excepcional de la privación de la libertad e identifica que su aplicación debe ser necesaria, adecuada, proporcional y razonable frente a los contenidos constitucionales. Asimismo, el artículo 296 del CPP, reitera la finalidad de la restricción de la libertad y señala que solo podrá ser afectada cuando sea necesario para satisfacer los fines constitucionales mencionados. Así, las medidas de aseguramiento y la regulación a la restricción de la libertad llevaron a un ordenamiento jurídico concentrado en dos objetivos: garantizar la administración de justicia como uno de los fines del proceso penal, y, proteger a las víctimas y a la sociedad, aunque ello signifique la privación de libertad del imputado.

Del análisis constitucional y legal de los requisitos y finalidades subyacentes a la limitación de la libertad, se observa que el legislador centró los lineamientos del orden jurídico penal de las medidas de aseguramiento en dos objetivos: garantizar la administración de justicia como uno de los fines del proceso penal; $y$, proteger a las víctimas y la sociedad, aunque ello signifique para el imputado privarlo de la libertad. Partiendo de que el derecho a la libertad no es absoluto y que puede ser limitado, se considera que es deber del Estado garantizar que se cumpla con las finalidades del proceso y al mismo tiempo brindar seguridad a la comunidad y a las víctimas, sin que ello implique la restricción de la libertad del imputado, especialmente cuando el legislador estableció una serie de medidas menos restrictivitas, menos lesivas para el individuo, en virtud de lo que el doctrinante Álvaro Orlando Pérez ha considerado como uno de los requisitos para

\footnotetext{
${ }^{39}$ Ley 906 de 2004, artículo 2.
} 
"reducir la libertad": la subsidiariedad40, sin embargo, la imposición de la detención preventiva privativa de la libertad sigue siendo la medida preferente de los jueces de control de garantías ${ }^{41}$.

\subsection{LOSFINES CONSTITUCIONALES}

Las medidas de aseguramiento tienen naturaleza cautelar porque garantizan el cumplimiento de fines que pueden ser de carácter procesal o sustancial, por eso prioriza la protección de la prueba, de la víctima y la comunidad y busca asegurar la comparecencia del procesado y el cumplimiento de la pena resultado de la sentencia condenatoria que declare la responsabilidad penal del individuo ${ }^{42}$. En igual sentido, la Comisión Interamericana de Derechos Humanos ${ }^{43}$ también incluye la posible evasión u obstaculización del accionar de la investigación judicial como un fin de la detención preventiva, ya que considera perentoria la efectiva realización del juicio, por lo que recomienda la imposición de esta medida cuando no existan otras formas de asegurar la presencia del imputado al juicio o de impedir la alteración de pruebas ${ }^{44}$.

En el caso colombiano, los fines constitucionales se entienden como el interés de protección que legitima la imposición de la detención preventiva, la cual necesariamente obedece a la satisfacción de uno de ellos y por eso exige la mediación de un análisis de necesidad45. Para cumplir este requisito debe efectuarse un juicio de proporcionalidad en el cual se concluya que la medida solicitada por el ente acusador es la que mejor se adecúa para alcanzar el fin invocado en el caso concreto. En ese sentido, no es posible concebir la imposición de la medida por capricho de un funcionario. Al respecto, la doctrina ha manifestado que:

No por elevar a rango constitucional los fines perseguidos con las medidas de aseguramiento puede decirse que hay en la regulación del régimen de libertad una concepción garantista, puesto que no resulta acertado bajo ninguna consideración, restringir un derecho o garantía fundamental, en aras de asegurar una atribución, obligación o deber del Estado, al no existir equivalencia entre esos dos extremos de la relación que permita ponderarlos ${ }^{46}$.

\subsubsection{Evitar la obstrucción de la justicia}

Este fin se ocupa fundamentalmente de garantizar la administración de justicia, el correcto desarrollo del proceso penal y evitar que el imputado se valga de maniobras para entorpecer las labores de investigación. Busca asegurar la preservación de los elementos materiales

\footnotetext{
${ }^{40}$ Pérez (2015), p. 89.

${ }^{41}$ Hernández (2018), p. 212.

42 Constitución Política de Colombia de 1991, art. 250.1; Ley 906 de 2004, art. 308.

${ }^{43}$ Convención Americana de Derechos Humanos (1969), art. 7.5.

${ }^{44}$ Comisión Interamericana de Derechos Humanos (2013), pp. 61 y 19.

${ }^{45}$ Corte Constitucional de Colombia, Sentencia C 1154 de 2005.

${ }^{46}$ Ospina (2015), p. 56.
} 
probatorios que van a servir al proceso, de manera que la labor del juez en su decisión consiste en establecer cuáles son esos "motivos [realmente] graves y fundados" por los cuales la libertad del imputado $-\mathrm{u}$ conceder otra medida menos gravosa- pone en riesgo las labores de investigación de la Fiscalía. Asimismo, este fin evita que quien interviene en el proceso penal actúe de manera contraria a la que se espera en el proceso por injerencia del procesado ${ }^{47}$. Lo anterior significa que no toda actuación por parte del imputado puede causar la restricción de su libertad. El juez no puede, por vía de hecho, extralimitar su poder de dirección del proceso penal. Se trata, por tanto, de un fin de "carácter y naturaleza eficientista" pero también de carácter procesal en la medida en que busca proteger el correcto desarrollo del proceso 48 .

Las actuaciones procesales deben encaminarse a la construcción de la verdad, de manera que las partes que intervienen en el proceso penal están en la obligación de aportar a la reconstrucción de los hechos, y las pruebas que en él se alleguen deben llevar al juez al "conocimiento" de los hechos que se están debatiendo en el proceso y a establecer con total certeza la responsabilidad penal del sujeto. Para Francesco Carnelutti, “cualquiera sea la sistemática procesal que se siga, el fin último de todo proceso penal es el descubrimiento de la verdad"49. Será el juez quien, en últimas, nos acerca con su decisión a la verdad de los hechos. Para la Corte este fin es válido porque:

El juez está habilitado para decretar medidas de aseguramiento a efectos de la conservación de las pruebas. Esta justificación debe ser observada como un criterio general que permite imponer afectaciones a la libertad en aras del normal desarrollo del proceso, evitar su obstrucción o entorpecimiento y específicamente proporcionar las condiciones para la integridad de las pruebas que interesan a la investigación ${ }^{50}$.

Teniendo en cuenta lo anterior, se cuestiona este fin en la medida en que no resulta admisible que se protejan las pruebas y los testigos limitando la libertad del imputado: es deber del Estado por medio de la Fiscalía garantizar la protección de ambos, sin que se sacrifique algún derecho fundamental. La Comisión Interamericana de Derechos Humanos admite la restricción a la libertad cuando hay interrogatorios difíciles y posiblemente pueden ser obstaculizados por los acusados, pero también reconoce que una vez concluida la investigación y disminuida la situación de peligro a partir de ella, no hay razón de necesidad válida para prolongar la detención preventiva51. Su imposición solo es legítima por el tiempo que tome la recaudación de las

\footnotetext{
${ }^{47}$ Constitución Política de Colombia de 1991, artículo 250.1; Ley 906 de 2004, artículo 309.

48 Ospina (2015), p. 57.

${ }^{49}$ Corte Constitucional de Colombia, Sentencia C 396 de 2007.

${ }^{50}$ Corte Constitucional de Colombia, Sentencia C 469 de 2016.

${ }^{51}$ Comisión Interamericana de Derechos Humanos (1997), Informe № 2/97, Caso Bronstein y Otros vs. Argentina, párrs. 33 y 35.
} 
pruebas e interrogatorios, de lo contrario dicho objetivo queda deslegitimado al no existir un interés que proteger 52 .

\subsubsection{Peligro para la comunidad y la víctima}

Este fin resulta válido para la imposición de la detención preventiva, pues el legislador fijó que el análisis del desarrollo normativo — artículos 310 y 311 del CPP-implica considerar el peligro de reiteración ${ }^{53}$ o posible comisión de nuevas conductas delictivas por parte del imputado en libertad a partir de criterios de gravedad y modalidad de la conducta delictiva ${ }^{54}$. En este sentido, la Comisión Interamericana ha señalado que no resulta admisible sustentar la imposición de la medida únicamente en criterios como: la peligrosidad del imputado, la posibilidad de reiteración de delitos, o la repercusión social del hecho, en tanto, son fundamentos del derecho penal material no procesal y son propios de la respuesta punitiva, asimismo, considera que atentan contra el derecho a la presunción de inocencia, el principio de interpretación pro homine, y contra el fin de la medida cautelar, el cual debe obedecer a neutralizar los riesgos procesales que pongan en peligro el desarrollo del contra el juicio y para ello considera validos: evitar la obstrucción a la justicia y el peligro de fuga55.

Pero ¿cuándo el imputado representa un peligro inminente para la comunidad o la víctima? es decir, hasta qué punto el juez al analizar los elementos consagrados en el CPP puede inferir de ellos que la libertad del imputado representa un peligro o ¿cuándo hablar de un peligro real para la víctima y la comunidad? Al respecto la Corte ha estimado que:

La prevención que se persigue en este caso está asociada a los riesgos y efectivas vulneraciones que, en el supuesto de no ser aplicadas las respectivas medidas, probablemente se seguirían para derechos fundamentales de terceros o de las víctimas. Esta causal de justificación encuentra su fundamento, como en su momento lo indicó la Corte, en el principio de la prevalencia del interés general y en los fines esenciales del Estado, de servir a la comunidad, promover la prosperidad general y garantizar los principios, derechos y deberes constitucionales ${ }^{56}$.

\subsubsection{La comunidad}

El fin constitucional de evitar el peligro para la comunidad, consagrado en el artículo 310 del CPP, parte de un análisis del elemento de peligrosidad para imponer la detención preventiva al

\footnotetext{
52 Barona citado en Ospina (2015), p. 57.

53 Palacios (2018), p. 94.

${ }^{54}$ Cruz (2012), pp. 90-92.

${ }^{55}$ Comisión Interamericana de Derechos Humanos (2009), Informe No. 86/09, Caso 12.553, Fondo, José,Jorge y Dante Peirano Basso, Uruguay, párrs. 81 y 84; Informe No. 77/02, caso 11.506, Fondo, Waldermar Gerónimo Pinheiro y José Víctor Dos Santos, Paraguay, 27 de diciembre de 2000, párr. 66.

${ }^{56}$ Corte Constitucional de Colombia, Sentencia C 469 de 2016.
} 
imputado. De acuerdo con el legislador los parámetros para determinarla son "la gravedad y la modalidad de la conducta punible, asimismo la pena imponible"57. Dicha normativa fue modificada por el artículo 24, Ley 1142 de 2007, donde el legislador consideró que la modalidad y gravedad de la conducta punible eran motivos suficientes para considerar que la libertad del imputado representa un peligro para la comunidad y dejó a potestad del juez evaluar otras circunstancias que contempla la norma procesal penal. De acuerdo con la norma citada, el fin debe salvaguardarse cuando la conducta lesione bienes jurídicos "importantes", pero deja a discreción del juez determinar cuáles son esos bienes jurídicos. La Corte estimó que por sí solos la gravedad y modalidad de la conducta no podían ser criterios para imponer la medida de detención con la justificación de proteger a la comunidad, por tanto, condicionó su exequibilidad, pues no serían los únicos criterios considerados para privar de la libertad al imputado, sino que se debía tener en cuenta si la detención preventiva era necesaria y proporcional para cumplir con los fines constitucionales de la misma58.

Posteriormente el artículo 65 de la Ley 1453 de 2011 reiteró que la gravedad y modalidad de la conducta punible eran criterios suficientes para determinar que el imputado representaba un peligro para la comunidad; además de considerar los fines constitucionales de la detención preventiva, esta ley añadió la necesidad de observar la valoración del juez con respecto a alguna de las circunstancias señaladas en ella. No obstante, para la Corte Interamericana, esta afirmación no aumenta las garantías a la libertad personal, sino que reafirma la atribución del juez —así sea flexible - de asumir criterios de gravedad en la conducta punible para prolongar la detención ${ }^{59}$, en reiterada jurisprudencia ha enfatizado que, aunque existan indicios que permitan inferir la participación del imputado en el ilícito, la privación de la libertad no puede fundamentarse en fines preventivo-generales o preventivo-especiales propios de la pena; por tanto, considera como único fin legitimo: asegurar que el acusado no impedirá el desarrollo del procedimiento ni eludirá la justicia. Reitera que las características personales del presunto autor y la gravedad del delito que se le imputa no son justificación suficiente para imponer la prisión preventiva ${ }^{60}$.

La última modificación al artículo 310 del CPP, el artículo 3 de la Ley 1760 de 2015 estableció como criterios suficientes para efectuarla, además de la gravedad y modalidad de la conducta

\footnotetext{
${ }^{57}$ Ley 906 de 2004, artículo 310 modificado por la Ley 1142 de 2007, modificado por Ley 1453 de 2011; y artículo 65 modificado por artículo 3 de la Ley 1760 de 2015.

58 Corte Constitucional de Colombia, Sentencia C 1198 de 2008.

${ }^{59}$ Comisión Interamericana de Derechos (2013), p. 40.

${ }^{60}$ Corte Interamericana de Derechos Humanos, 21 de noviembre de 2007, párr.93.
} 
punible, pena a imponer y la valoración de las circunstancias especiales enumeradas por la Ley 1453 de 2011. Sin embargo, la Corte estimaba que la discusión en torno a la peligrosidad había sido superada. En su razonamiento este es un concepto que atenta contra la presunción de inocencia del imputado y genera una presunción de culpabilidad, que llevaría a un claro retroceso al pasar del derecho penal de actor para volver al derecho penal de actor. Así la Corte concluyó que el debate no debía darse sobre el imputado como persona, sino sobre sus actos y de estos se deriva la posibilidad de reiteración o comisión de nuevos hechos punibles, es a partir de ellos, que debe realizarse el análisis para la imposición de la medida restrictiva de la libertad 61.

Con base en lo anterior, se considera que al tener en cuenta la posibilidad de reiteración, se le imprime a la imposición de la medida un carácter preventivo especial propio de la pena ${ }^{62}$. Presumir que el imputado podría ser a futuro un peligro para la comunidad es tratar de subsanar en un estadio procesal incorrecto las falencias de política criminal y de prevención del delito que tiene el Estado colombiano. Si bien la seguridad de la comunidad y su protección frente a la futura comisión de delitos constituyen fines sobre los cuales se fundamenta el Estado, no resulta admisible que satisfaga las finalidades de prevención, protección y seguridad limitando la libertad del individuo, máxime cuando aún está amparado por la presunción de inocencia, esto es, por las garantías propias del proceso penal. En ese sentido, la Corte Interamericana de Derechos Humanos afirma que cada Estado puede adoptar desde el derecho penal medias preventivas de la delincuencia, pero aclara que esa no es una de las funciones de la detención preventiva 63.

\subsubsection{La víctima}

Dada la importancia de la víctima en el desarrollo del proceso penal por ser la persona en la cual se materializa la comisión de la conducta típica, es decir, por ser a quien se lesionan sus derechos con la conducta reprochable realizada por el presunto responsable, la aplicación de la detención preventiva busca evitar que esa lesión se repita o que se ocasionen nuevos daños ${ }^{64}$. Con la privación de la libertad del imputado se protegen los derechos fundamentales de la víctima: vida, integridad física, honra, bienes y familia. Al respecto, la ley penal consagra una

${ }^{61}$ Corte Constitucional de Colombia, C 469 de 2016.

62 Mir (2018), p. 94.

${ }^{63}$ Corte Interamericana de Derechos Humanos, 29 de mayo de 2014, párr. 361.

${ }^{64}$ Por ello la Corte Interamericana de Derechos Humanos es enfática en declarar como único fin de la detención preventiva el garantizar el proceso y nunca prevenir, por ejemplo, la comisión de delitos futuros. Esta es una atribución que corresponde a la condena, y por eso al aplicarse durante la detención preventiva se violan derechos individuales como la presunción de inocencia. Comisión IDH, informe N 77/02, Caso Gerónimo Pinheiro y otro vs. Paraguay, párr. 66. 
carta de bienes jurídicos que se tutelan y representan los derechos o principios que merecen especial protección.

Para evitar peligros, el legislador consagró expresamente como un fin constitucionalmente válido para la imposición de la medida de aseguramiento, la protección de la víctima. Esta pretende garantizar la no repetición de conductas que atenten nuevamente contra ella y parte de la presunción de que la libertad del imputado representa un peligro, y que con base en "motivos fundados" se puede inferir la posible reiteración de conductas punibles que lesionarían los derechos protegidos de la víctima65. Esta adquiere la calidad de interviniente especial, lo que la faculta para participar dentro de las actuaciones del proceso penal con la finalidad de "asegurar el goce de sus derechos a la verdad, la justicia y la reparación [no repetición]"66. Igualmente, el artículo 11 del CPP estableció algunos derechos de las víctimas. Por ejemplo, con relación a la medida de aseguramiento, el legislador las facultó para solicitar su imposición cuando el fiscal la omitiera —artículo 306-. Frente a esto la Corte Constitucional considera que:

Cuando la solicitud de la medida de aseguramiento la formule el fiscal, el juez de Control de Garantías deberá evaluar la concurrencia de los requisitos previstos en el [artículo 308 del CPP.] pero cuando la solicitud provenga de las víctimas, además de estos requisitos, el juez deberá evaluar uno adicional consistente en los motivos que "sustentan" la omisión del fiscal de solicitar la imposición de una medida de aseguramiento y así determinar la viabilidad de la imposición67.

Los artículos 250 numerales 1 y 5 de la constitución y el artículo 342 del CPP atribuyen a la Fiscalía el deber de velar por la protección de la comunidad y de las víctimas y solicitar los mecanismos necesarios para restablecer y reparar el derecho lesionado con la comisión de la conducta punible; objetivo que se puede cumplir mediante la medida de protección que considere más eficaz. Si bien se ha señalado que los principales derechos de las víctimas en el proceso penal son justicia, verdad, reparación y no repetición, también puede agregarse al núcleo, la protección de los bienes jurídicos que tutela la ley penal, en tanto ellos obedecen al desarrollo legal de la constitución, protegen los derechos fundamentales y los principios que irradian todo el orden jurídico. Cada título consagrado en la ley penal corresponde a un derecho que el legislador, basado en políticas criminales, le dio una especial protección: “Negar el bien

${ }^{65}$ Ley 906 de 2004, artículo 311

${ }^{66}$ Corte Constitucional de Colombia, Sentencia C 588 de 2019.

${ }^{67}$ Ley 906 de 2004, artículo 306. 
jurídico es negar que el hombre como individuo tiene derechos y que los derechos necesitan protección, siendo este el deber esencial del Estado"68.

Generalmente, con la justificación de proteger los derechos de las víctimas o de evitar que sean lesionados nuevamente se limita la libertad del imputado. Este fin genera una verdadera tensión entre los fines de la detención preventiva y los derechos fundamentales. Por sus características, podría considerarse como el único realmente válido para imponer una medida de aseguramiento. Hasta el momento los fines constitucionales revisados que habilitan la aplicación de la medida buscan la protección de finalidades que el Estado debería satisfacer: eficacia de la justicia, orden público, adecuado desarrollo del proceso penal, prevalencia del interés general, sin tener que recurrir a la limitación de un derecho fundamental; mientras que la protección de víctimas se remite a proteger derechos en particular.

\subsubsection{No comparecencia}

Es un fin que apunta a la protección del proceso penal y responde a la necesidad del Estado por hacer que la justicia sea eficaz y que al momento de una eventual condena sea posible materializarla —artículo 312 del CPP. modificado por el artículo 5 de la Ley 1142 de 2007-. El legislador estableció unos criterios esenciales para determinar la eventual no comparecencia del imputado: gravedad, modalidad de la conducta y pena imponible. También se consideran los siguientes factores: falta de arraigo en la comunidad, determinado por el domicilio; asiento de la familia, de sus negocios o trabajo; facilidades que tenga para abandonar el país o permanecer oculto; gravedad del daño causado; la actitud que el imputado asuma frente a este; y el comportamiento del imputado durante el procedimiento o en otro anterior, del que se infiera razonablemente su falta de voluntad para sujetarse a la investigación, la persecución penal y al cumplimiento de la pena.

En este fin se presenta un análisis acerca de la peligrosidad del imputado y de los criterios señalados; es un criterio que se cuestiona, en la medida que se presume la fuga por el solo hecho de estar siendo investigado por un delito "grave" y "la actitud que el imputado asuma frente a este”. Al respecto surgen algunas inquietudes: ¿cuál debe ser la actitud que asuma un imputado frente al proceso?, ¿la de cooperación? De ser así, este sería un fin que busca el allanamiento o la confesión, lo que resultaría más peligroso que el imputado mismo, pues se buscaría el sometimiento so pena de restringir la libertad. La Comisión Interamericana ha señalado que en

${ }^{68}$ Fernández (2013), p. 273. 
Colombia la detención preventiva se usa, indebidamente, como herramienta de investigación, ya que sin la suficiente evidencia los fiscales recurren a ella para presionar a los procesados a la entrega de pruebas o aceptación de cargos ${ }^{69}$.

De acuerdo con lo anterior, este fin se fundamenta en una presunción, por lo que se considera un argumento que resulta insuficiente para restringir un derecho fundamental. Adicionalmente, la mención al comportamiento del imputado durante un procedimiento anterior parte de una presunción de causalidad en el sentido de que si en el proceso anterior no compareció en el que se esté llevando a cabo en el presente tampoco lo hará. Para Ferrajoli el peligro de fuga está vinculado directamente con el temor a la prisión preventiva. Si el proceso penal tuviera como máxima expresión real la defensa en libertad, el procesado tendría un estímulo positivo para permanecer, asumir su defensa y no escapar ${ }^{70}$.

\subsubsection{Conclusiones sobre los fines constitucionales en la detención preventiva}

Los fines constitucionales válidos presentan una característica común o un gran fin: brindar seguridad, bien al proceso con la administración de justicia y la eficacia de esta; o a las víctimas y la comunidad con la cesación y prevención de la comisión de delitos. La doctrina ha considerado que los fines de la detención preventiva llevan implícitos otras finalidades "no oficiales", "encubiertas", "no declaradas" y "reales" que otorgan eficacia a la detención preventiva y la revelan como una opción deseable en la lucha contra la delincuencia. Sin embargo, en su pretensión de "satisfacer una demanda social", "obtener cooperación", "reestablecer el sentimiento de seguridad ciudadana" y mitigar "la alarma social creada por el delito", la medida pierde su naturaleza cautelar y procesal, estos objetivos degeneran en funciones preventivas generales y especiales que solo son posibles en el marco de la pena, incluso, de la política criminal del Estado ${ }^{71}$.

La aplicación de la detención preventiva es un medio para alcanzar uno de los fines constitucionales. Aunque el Estado cuenta con una lista de alternativas menos restrictivas, en la práctica es común que el ente acusador opte inmediatamente por la detención preventiva. Al momento de aplicarla se produce así una "colisión" entre el derecho fundamental a la libertad del imputado y alguno de los fines constitucionales que se quiere satisfacer. Cualquiera de los

${ }^{69}$ Comisión Interamericana de Derechos Humanos (2013), p. 28.

70 Ferrajoli (2011), p. 558.

${ }^{71}$ Sandoval y Del Villar (2013), pp. 133-134. 
conflictos que se presente, la solución adecuada es la aplicación del principio de proporcionalidad.

\section{Ponderación: solución a los conflictos entre derechos fundamentales y fines constitucionales}

Generalmente cuando se presenta un conflicto entre derechos fundamentales es necesario llevarlos al campo de los principios para así lograr una ponderación entre ellos. La institución jurídica de la ponderación ha sido definida por la doctrina como:

[...]Buscar la mejor decisión (la mejor sentencia, por ejemplo) cuando en la argumentación concurren razones justificadoras conflictivas y del mismo valor. Lo dicho sugiere que la ponderación es un método para la resolución de cierto tipo de antinomias o contradicciones normativas. Desde luego, no de todas: no de aquellas que puedan resolverse mediante alguno de los criterios al uso, jerárquico, cronológico, o de especialidad 72 .

Los principios se definen como "mandatos de optimización que se caracterizan porque pueden cumplirse en diferente grado y la medida debida de su cumplimiento no solo depende de las posibilidades reales sino también las jurídicas"73. Las posibilidades fácticas obedecen a aspectos presupuestarios y de viabilidad física, mientras que las jurídicas son los principios que se encuentran en el sentido contrario. De esta manera, los derechos fundamentales, por su estructura y redacción abstracta, son ejemplo de principios ${ }^{74}$. En materia de detención preventiva debe entenderse el derecho fundamental a la libertad del imputado como un principio que colisiona con los fines constitucionales y los derechos — principios- de los demás intervinientes del proceso penal. En ese contexto, es necesario acudir al principio de proporcionalidad el cual exige que las cargas asumidas por el individuo con la restricción de su derecho fundamental compensen las ventajas obtenidas. Las razones que justifican la intromisión en la esfera de los derechos del imputado deben ser trascendentes y satisfacer el fin:

Para Bernal, el Estado puede restringir los derechos "a partir del acto fundacional de la sociedad civil", dicha sociedad sentó sus bases en la armonización del "ejercicio de los derechos de los distintos titulares" de esta manera, por medio de las reglas jurídicas se valió para superar el "caos que produce la libertad absoluta"75. Por ello, a este principio se le ha atribuido una justificación teleológica como presupuesto material que permite hacer un "análisis de los valores o principios que se buscan proteger con la medida restrictiva"76.

\footnotetext{
72 Prieto (2009), p. 137.

${ }^{73}$ Alexy (2017), p. 68.

${ }^{74}$ Bernal y Montealegre (2013), p. 393.

${ }^{75}$ Bernal (2008), p. 81.

${ }^{76}$ Bernal y Montealegre (2013), p. 415.
} 
Jurisprudencialmente se ha reconocido que la proporcionalidad es un principio de interpretación constitucional "en su función como el marco del Estado de derecho que busca asegurar que el poder público actúe dentro de sus competencias y sin excederse en el ejercicio de sus funciones"77. De igual forma, indica que como juicio rector de las actuaciones públicas permite determinar — en materia de control jurisdiccional de constitucionalidad- cuando una norma genera afectación iusfundamental que resulta excesiva para el beneficio que reporta. En el caso de la Corte, la proporcionalidad le ha permitido realizar ponderaciones entre:

(i) El establecimiento de una serie de medidas que tienen por finalidad la consecución de un objetivo constitucionalmente admisible, deseable o válido;

(ii) La correlativa afectación que con la adopción de este tipo de medidas se puede generar; y

(iii) La necesidad que existe de incurrir en dicha afectación, así como la imposibilidad de lograr esa finalidad por otros medios menos lesivos ${ }^{78}$.

La Corte ha desarrollado este principio, como el mecanismo constitucional que permite equilibrar el diseño legislativo judicial porque regula la arbitrariedad en el ejercicio de la autoridad penal al momento de restringir la libertad del imputado mediante la detención preventiva. El legislador cuenta con las normas cautelares como marco general de actuación, pero su severidad está limitada por la relación de proporcionalidad, es decir, por la existencia de un "equilibrio razonable y ponderado" entre la severidad de esa política criminal y el fin que esta persigue dentro del proceso penal; fin que no debe poner en riesgo los derechos fundamentales de los ciudadanos y del procesado. Esta función reguladora del principio de proporcionalidad ha sido reiterada en varias ocasiones por la Corte. Así en el 2008, había indicado que la potestad legislativa en cuanto a las medidas de aseguramiento es relativa, porque más allá de la injerencia cautelar — conveniencia y oportunidad - deben cumplirse fines constitucionalmente admisibles y protegerse los derechos fundamentales. Entre 1997 y 2008 la Corte enfatizó en la necesidad de resguardar los derechos y sus limitaciones de los excesos. En ese sentido, los supuestos concedidos por el legislador para justificar una acción tan restrictiva como la detención preventiva deben basarse en un equilibrio razonable que evite alterar un derecho que no es absoluto, pero tampoco puede serlo su restricción ${ }^{79}$.

Según estas afirmaciones, el principio de proporcionalidad es el marco de referencia idóneo para conservar la estabilidad del derecho a la libertad personal, en tanto ofrece una alternativa razonable para determinar los supuestos de enunciación y aplicación de su restricción cuando

77 Corte Constitucional de Colombia, Sentencia C 144 de 2015.

${ }^{78}$ Corte Constitucional de Colombia, Sentencia C 144 de 2015.

79 Ob. Cit., Sentencia C 327 de 1997; Sentencia C 634 de 2000; Sentencia C 318 de 2008. 
es inevitable dicha intromisión por parte de la autoridad. Este principio busca el predominio de un análisis de ecuanimidad en el que prevalece el cumplimiento del derecho como estándar de actuación, lo que significa que su limitación estaría "ampliamente justificada" y sería una medida excepcional80. Este principio está unido al de presunción de inocencia, lo cual supone un condicionamiento a la intención de privar de la libertad al imputado dentro de proceso penal y una clasificación diferencial de su naturaleza, pues la detención provisional sería preventiva y no sancionatoria. La Corte puntualiza que la detención preventiva durante la investigación y juzgamiento del imputado no siempre se da bajo la forma de "privación efectiva y material de la libertad individual” y garantiza que cuando ocurra será por "la necesidad de que se cumplan los fines de la investigación penal"81.

El criterio de moderación basado en la presunción de inocencia y en la proporcionalidad es clave para que la detención del procesado sostenga un carácter preventivo y no punitivo ${ }^{82}$; situación que supondría un desborde de la potestad, pues la privación de la libertad solo puede ocurrir con el objetivo de cumplir razonablemente con unos fines o bienes previamente establecidos. Esa naturaleza preventiva elimina la aparente contradicción entre detención y presunción de inocencia, la medida no establece responsabilidad penal en el procesado. Pero, la preservación de ese carácter depende del principio de proporcionalidad, en términos prácticos detener implica suspender materialmente la libertad personal y si no se justifica la excepción a este derecho, la detención tomaría un cariz sancionatorio que anularía el derecho a la presunción de inocencia83. Así, la Corte señala en sentencia C 469 de 2016 que el principio de proporcionalidad se da en la concurrencia de dos criterios: necesidad y gradualidad.

\subsection{LANECESIDAD COMO CRITERIO DE PROPORCIONALIDAD}

De acuerdo con lo anterior, el principio de proporcionalidad — considerado en las medidas de aseguramiento- propende porque el legislador compense razonablemente el bien que se quiere asegurar con la limitación a los derechos del procesado, que su sacrificio sea mínimo, que se logre el objetivo invocado ${ }^{84}$. Para efectuarlo, la Corte ha jerarquizado unos criterios que hacen exequible la aplicación de medidas privativas de la libertad a una persona investigada

\footnotetext{
${ }^{80}$ González (2009), p. 455. Hace referencia a la excepcionalidad desde el Derecho Internacional de los Derechos Humanos.

${ }^{81}$ Corte Constitucional de Colombia, Sentencia C 469 de 2016.

${ }^{82}$ La Corte IDH establece que: "De lo dispuesto en el artículo 8.2 de la Convención se deriva la obligación estatal de no restringir la libertad del detenido más allá de los limites estrictamente necesarios para asegurar que no impedirá el desarrollo eficiente de las investigaciones y que no eludirá la acción de la justicia, pues la detención preventiva es una medida cautelar, no punitiva". Corte Interamericana de Derechos Humanos, 12 de noviembre de 1997, párr.77.

83 Corte Constitucional de Colombia, Sentencia C 689 de 1996; Sentencia C 774 de 2001.

${ }^{84}$ Corte Constitucional de Colombia, Sentencia C 805 de 2002.
} 
judicialmente. El primero es la necesidad jurídica — que no política ni estratégica一, es decir, la existencia de una justificación según los hechos de cada caso concreto y que motiva el cumplimiento de un fin superior en el proceso penal general y en la medida cautelar específica, o sea, que haya un beneficio proporcionalmente equivalente a la limitación impuesta al afectado.

La Comisión Interamericana considera que el criterio de necesidad obedece a la necesidad de imponerse solo cuando sea indispensable para alcanzar los objetivos propuestos. Es decir que, solo procederá cuando sea el único medio que permita asegurar los fines del proceso, y deberá demostrarse que otras medidas cautelares menos lesivas no serían suficientes para alcanzar el fin. Asimismo, agrega que deberá ser sustituida por una medida cautelar menos gravosa cuando las circunstancias lo permitan. El criterio de necesidad es relevante al momento de decir la imposición de la medida, y al momento de evaluar la pertinencia de su prolongación; por tanto, es deber del órgano pertinente, aun de oficio, disponer la libertad del procesado cuando hayan cesado los motivos que dieron origen a su imposición. De acuerdo con la naturaleza cautelar que justifica la medida de aseguramiento, solo puede estar vigente durante el lapso estrictamente necesario para garantizar el fin procesal propuesto. Finalmente, para la Comisión "La detención preventiva de una persona no debe prolongarse por un periodo más allá del cual el Estado pueda dar una justificación adecuada de la necesidad de esta, de lo contrario la privación de libertad se torna arbitraria" 85 .

En Colombia como Estado social de derecho cualquier limitación a la libertad y a la presunción de inocencia es indeseable, de manera que su restricción en el procesado nunca responderá al capricho de conveniencia del fiscal, sino que debe ser el resultado estrictamente necesario cuando el objetivo invocado no pueda resolverse mediante otra orden cautelar menos lesiva a las prerrogativas constitucionales o derechos fundamentales. El criterio de necesidad es un componente esencial de la proporcionalidad por cuanto asegura que el "medio empleado [resulte] indispensable para alcanzar el objetivo propuesto" 86 .

Este criterio solo es el inicio, porque a continuación el proceso debe evidenciar que los fines buscados a partir de la medida de aseguramiento son constitucionalmente relevantes y admisibles. El artículo 250 de la constitución al enunciar que tales medidas podían usarse como

${ }^{85}$ Comisión Interamericana de Derechos Humanos (2009), Informe No. 86/09, Caso 12.553, Fondo, José, Jorge y Dante Peirano Basso, Uruguay, párrs. 100,102 y 105.

${ }^{86}$ Corte Constitucional de Colombia, Sentencia C 469 de 2016. En 2012 declaró inexequible el artículo 65 de la Ley 1453 de 2011 , donde el juez podía considerar peligroso para la comunidad a quien tuviera medida de aseguramiento o alguna medida sustitutiva, por condena o por acusación, hechos muy diferentes entre sí y cuyo uso indiscriminado resultaba desproporcionado. Sentencia C 121 de 2012. 
medio para restablecer el derecho infringido y, sobre todo, como un mecanismo para proteger a los intervinientes en el proceso, ofrece un primer fin constitucional que justifica el uso de la detención preventiva - una vez verificada su necesidad - si el objetivo es preservar la prueba — testigos y otras evidencias en fundado peligro— 87 .

Los artículos 1 y 2 de la constitución al indicar que el Estado de derecho se fundamenta en el “interés general” y que su finalidad es conservar la convivencia pacífica proporciona un segundo fin constitucionalmente permitido y es proteger a la comunidad de actividades delictivas que continuarían si no se toma la medida de aseguramiento. En ese sentido, cualquier otro criterio de procedencia sobre la misma que no se ajuste a la carta política podría ser objeto de juicio constitucional. La actualización de la norma refrendó así el criterio de necesidad como razón de la decisión judicial, pues con la mediación del juez de control de garantías se asegura que la detención preventiva será usada solamente cuando sea indispensable o insustituible por otra medida más leve. El Acto Legislativo 03 de 2002 permite que la detención preventiva cumpla con los tres fines constitucionales mencionados y responda a un equilibrio entre el interés general y los derechos individuales.

Dicha medida cautelar evita la fuga del procesado, y así se pueda efectuar un juicio sin rebeldía procesal en donde se respeten los derechos a la defensa y al debido proceso - artículo 29 de la constitución-y que asegure el cumplimiento de una eventual condena a pena privativa de libertad. La nueva norma habilitó la detención como mecanismo legítimo para impedir la obstrucción del proceso y cuidar la integridad de las pruebas de investigación. Por último, la jurisprudencia priorizó la protección de los derechos fundamentales de terceros, pues, el interés, la prosperidad y la constitucionalidad son fines estatales esenciales, además de la convivencia pacífica, el orden justo y la efectividad del mandato que ampara bienes y derechos de los ciudadanos. Cuando la libertad del procesado vulnera a la comunidad y, especialmente, a las víctimas del delito concreto, el juez apelará a este fin para recurrir razonablemente a la detención preventiva.

\subsection{GRADUALIDAD COMOCRITERIO DE PROPORCIONALIDAD}

En la jerarquización que la Corte estableció para hacer exequible la detención preventiva, la gradualidad se sitúa como el segundo criterio que nutre la proporcionalidad requerida en su ejecución. Aunque es una característica incluida en los Códigos de Procedimiento Penal, su

${ }^{87}$ Corte Constitucional de Colombia, Sentencia C 318 de 2008; Sentencia C 774 de 2001. 
principal función es servir como baremo auxiliar para precisar con mayor claridad los límites legislativos al momento de restringir la libertad. La misión del legislador es asegurar el normal desarrollo del proceso penal según las condiciones de cada delito, pero su marco general de actuación es la excepcionalidad a la restricción de la libertad, por tanto, dentro de cada proceso su deber es priorizar las medidas menos invasivas a la libertad y a otros derechos fundamentales. La gradualidad exige al ente investigador o a quien presente la solicitud de la medida restrictiva de la libertad, que pruebe por qué las medidas no privativas resultan insuficientes para garantizar el cumplimiento del fin invocado88.

Como consecuencia del criterio de necesidad — según el cual la limitación a la libertad se compensa en el logro de un fin constitucional superior- surge el criterio de gradualidad que impide la existencia de una regla universal, estática, absoluta y abstracta para el análisis de justificación de la medida cautelar. Dicha restricción a la libertad es la excepción y no la regla, el juez debe apelar, en cada caso específico, a un esquema diferencial de medidas graduales previsto en la ley y que se adaptará al contexto correspondiente. De hecho, esa obligación hermenéutica y pragmática del juez es una expresión en sí del principio de gradualidad.

\subsection{CONCLUSIONES SOBRE LOS LÍMITES SUSTANCIALES QUE RESTRINGE LALIBERTAD}

De acuerdo con lo anterior, se observa que la Corte estableció cuatro instrumentos para limitar sustancialmente los excesos al usar las medidas de aseguramiento: "La estricta legalidad de los motivos que dan lugar a dicha afectación; su excepcionalidad; su proporcionalidad; y su gradualidad" 89 . El primero se refiere al grado de certeza sobre la responsabilidad del imputado, la cual se determina a partir de unos criterios predeterminados unívocamente por el legislador. Sin embargo, como la medida de aseguramiento responde a un criterio de necesidad contextual - “desconocido ex ante"-, esa regulación se flexibiliza porque demanda una adaptación y una interpretación de las circunstancias lo que lleva a una situación de discrecionalidad.

Por su parte, la excepcionalidad alude al imperativo del legislador de desarrollar normas que refuercen el carácter extraordinario de una medida tan drástica y lesiva e impida su uso generalizado. De ahí que la proporcionalidad dependa de este principio, pues ofrece un estándar para que el legislador pondere cuándo —o sea excepcionalmente- los fines buscados por la ley compensan la afectación del derecho individual a la libertad. Por este motivo que la

${ }^{88}$ Del Villar (2016), p.101.

${ }^{89}$ Corte Constitucional de Colombia, Sentencia 469 de 2016. 
proporcionalidad está ligada, a su vez, al derecho a la presunción de inocencia, si el proceso se ajusta al criterio de necesidad, es decir, a su inevitable aplicación que la hace legítimamente irremplazable por otra medida moderada, la detención se mantendrá en su carácter de preventiva sin cruzar el límite de lo sancionatorio. Entonces, el criterio de necesidad justifica la restricción a la libertad por cuanto proporciona las evidencias para que su aplicación solo se dé cuando fuere indispensable para proteger bienes constitucionales que expresan fines esenciales del Estado como cuidar el interés general y la convivencia pacífica.

La constitución en su artículo 250 ofrecía tres fines concretos que habilitaban la detención preventiva: protección de pruebas, de la comunidad/víctima e impedimento a la comisión de más acciones delictivas. Para ajustar la carta magna a la jurisprudencia constitucional reciente, el Acto Legislativo 03 de 2002 refinó el artículo 250 porque incluyó la figura del juez de control de garantías, como símbolo e instrumento de proporcionalidad para velar porque siempre se evidencie una finalidad constitucional en la privación de la libertad. Dicho Acto consolidó constitucionalmente los bienes invocados al restringir la libertad del imputado.

La gradualidad es un criterio complementario y evaluativo pues permite verificar si la decisión del juez que limitará la libertad del procesado es excepcional, proporcional y necesaria. Así, la gradualidad es el correlato de la excepción porque si algo es extraordinario exige un análisis ponderado de las distintas opciones cautelares, menos invasivas de los derechos fundamentales que se podrían aplicar antes de asumir como necesaria la más restrictiva. En el caso de que sea una medida necesaria — inevitable - la gradualidad también tendrá injerencia por cuanto esa necesidad se determina con base en un esquema diferencial y no a partir de reglas unívocas, pues es imprescindible considerar diversos factores de la circunstancia concreta para el análisis de la justificación y supone una actividad de subsunción que conlleva a un amplio margen de discrecionalidad.

\section{Conclusiones}

A la luz de la constitución colombiana y de su desarrollo jurisprudencial posterior, la detención preventiva resulta ajustada a ella aun cuando se limite el derecho fundamental a la libertad, pues la característica de esos derechos es que pueden ser limitados cuando la restricción obedezca a la satisfacción de los fines constitucionales requeridos en cada caso concreto. En este sentido, la detención preventiva se constituye únicamente en un medio y no en 
un fin para su satisfacción. La limitación del derecho fundamental a la libertad no puede ser un capricho de los operadores jurídicos, sino que está dispuesto todo un andamiaje jurídico para que esa limitación se aplique únicamente con la finalidad de maximizar otros fines como proteger las evidencias probatorias, a víctimas, a la comunidad y a garantizar la asistencia del imputado al proceso penal.

Estos objetivos son esenciales porque llevan implícitamente al cumplimiento de fines estatales. La imposición de la detención preventiva provoca en la sociedad la sensación de que la justicia está siendo efectiva, por ende, no se están quedando en la impunidad los delitos; en apariencia, el aparato judicial está velando por el interés general y el orden público. Contrario a lo que establece el sistema interamericano para quien la detención preventiva solo es válida en tanto se imponga para garantizar el normal desarrollo del proceso y la asistencia al mismo. La conclusión esencial de este artículo es que la medida resulta innecesaria con respecto a estos fines procesales por cuanto es el Estado quien debe contar con un poder amplio y suficiente para satisfacerlos sin limitar los derechos fundamentales de los individuos. La restricción de los derechos fundamentales del individuo — en este caso la libertad - no debe ser la solución a las falencias estatales en la administración de justicia. Por tanto, aunque la protección de pruebas ha sido consagrada en la constitución como un fin constitucional válido, no por ello debe aceptarse como fácticamente admisible.

En cuanto a los fines de protección de la comunidad y de las víctimas sí pueden considerarse realmente válidos para la imposición de la medida de aseguramiento privativa de la libertad, y con ellos existe una verdadera tensión entre derechos fundamentales. Se puede decir que las víctimas sufren un impacto concreto, de no aplicarse dicha medida; sus derechos fundamentales se verían eventualmente afectados. La detención preventiva protege sus bienes jurídicos particulares. Asimismo, ocurre con los bienes jurídicos colectivos que se tutelan en la comunidad, quien merece ser protegida de la comisión de futuros delitos. El análisis para imponer dicha medida no debe hacerse desde la presunción de peligrosidad que significaría la libertad del imputado, pues el derecho penal de actor quedó proscrito desde la constitución de 1991 y presumir que la libertad de un individuo representa un peligro es presumir la culpabilidad.

En este aspecto el Estado aún no ha establecido una política clara que logre un equilibrio entre salvaguardar la presunción de inocencia, la libertad del imputado y, simultáneamente, proteger los derechos de las víctimas y de la comunidad. En la actualidad el Estado cuenta con 
una "carta" de medidas menos restrictivas que no interfieren en la libertad individual; sin embargo, en el imaginario colectivo de la ciudadanía y de algunos administradores de justicia sigue vigente la idea de que la prisión constituye el mecanismo por antonomasia para la prevención y solución a la comisión de delitos; por esto se entiende a la prisión preventiva como un castigo y no como medida preventiva.

\section{Bibliografía citada}

Alexy, Robert (2014): “De la ponderación y la subsunción. Una comparación estructural”, en Montealegre, Eduardo, Bautista, Nathalia y Vergara, Felipe, comps., La ponderación en el derecho. Evolución de una teoría, aspectos críticos y ámbitos de aplicación en el derecho alemán (Bogotá, Universidad Externado de Colombia), pp. 39-62.

(2017): Teoría de los derechos fundamentales (Madrid, Centro de Estudios Políticos y Constitucionales Ministerio de la Presidencia).

Bernal, Carlos (2008): El derecho de los derechos (Bogotá, Universidad Externado de Colombia).

Bernal, Jaime y Montealegre, Eduardo (2013): El proceso penal. Tomo I: fundamentos constitucionales y teoría general (Bogotá, Universidad Externado de Colombia).

Bieri, Peter (2017): La dignidad Humana. (Barcelona, Herder).

Clavijo, Darwin, Guerra, Débora y Yáñez, Diego. (2014): Método, metodología y técnicas de la investigación aplicada al Derecho (Bogotá, Universidad de Pamplona - Ibáñez).

Cruz, Leonardo (2012): "Fundamentos de la detención preventiva en el procedimiento penal colombiano", en Derecho Penal y Criminología (Vol. 33, № 95), pp. 69-100.

Del Villar, Donaldo (2016): Prisión anticipada. A propósito del marco legal vigente en Colombia (Medellín, Sánchez R.).

Fernández, Juan (2013): Derecho penal. Parte general. Principios y categorías dogmáticas (Bogotá, Ibáñez).

Ferrajoli, Luigi (2007): “Derechos fundamentales”, en De Cabo, Antonio y Pisarello, Gerardo, eds., Los fundamentos de los derechos fundamentales (Madrid, Trotta) pp. 19-52. 
(2011): Derecho y Razón (Madrid, Trotta).

(2016): Los derechos y sus garantías (Madrid, Trotta).

García, Dora (2015): “la metodología de la investigación jurídica en el siglo XXI”, en Godínez, Wendy Aidé y García, José, coords., Metodologías: enseñanza e investigación jurídicas. 40 años de vida académica. Homenaje al doctor Jorge Witker electrónica (Ciudad de México, UNAM), pp. 449-465.

Gargarella, Roberto (2016): Castigar al prójimo. Por una refundación democrática del derecho penal (Argentina, Siglo veintiuno).

González, Antonio (2009): La detención preventiva en el procedimiento penal acusatorio (Bogotá, Leyer).

Hernández, Norberto (2018): El derecho penal de la cárcel. Una mirada al contexto colombiano con base en el giro punitivo y la tendencia al mayor encarcelamiento (Bogotá, Siglo del Hombre).

Mir, Santiago (2018): Derecho penal Parte general (Montevideo y Buenos Aires, B de F).

Ospina, Guillermo (2015): La inconstitucionalidad de la detención preventiva (Bogotá, Universidad Sergio Arboleda).

Palacios, Luis (2016): Límites temporales a las medidas de aseguramiento en el proceso penal (Bogotá, Ibáñez).

(2018): Detención preventiva y control de convencionalidad. El "peligro para la comunidad" desde la perspectiva del Sistema Interamericano de Derechos Humanos" (Bogotá, Ibáñez).

Pérez, Álvaro (2015): Los principios generales del proceso penal (Bogotá, Temis).

Prieto, Luis (2009): “Neoconstitucionalismo y ponderación judicial”, en Carbonell, Miguel, ed., Neoconstitucionalismo(s) (Madrid, Trotta).

Sampedro, Camilo (2012): “Detención preventiva y seguridad ciudadana”, en XXIV Jornadas Internacionales de Derecho Penal (Bogotá, Universidad Externado de Colombia). 
Sandoval, Jaime y Del Villar, Donaldo (2013): Responsabilidad penal y detención preventiva: el proceso penal en Colombia. Ley 906 de 2004 (Barranquilla, Universidad del Norte - Ibáñez).

Sorza, Fabio (2016): "La detención preventiva en Colombia frente al principio de libertad en los derechos humanos", en Revista Análisis Internacional (Cesada a Partir De 2015) (Vol. 6, № 2), pp. 39-66.

Urbano, José (2006): “Los fines constitucionales del proceso penal como parámetros de control del principio de oportunidad", en Derecho Penal y Criminología (Vol. 27, № 80), pp. 111-128.

Villabella, Carlos (2020): “Los métodos en la investigación jurídica. Algunas precisiones”, en Cáceres, Enrique, coord., Pasos hacia una revolución en la enseñanza del derecho en el sistema romano-germánico, tomo 4, versión electrónica (Ciudad de México, Universidad Nacional Autónoma de México), pp. 921-953.

Zavaleta, Arturo (1954): La prisión preventiva y la libertad provisoria (Buenos Aires, Arayú).

\section{Normas jurídicas citadas}

Constitución Política de Colombia, julio de 1991.

Ley 599 de 2000, de 24 de julio, por la cual se expide el Código Penal. Diario Oficial № 44.097, 24 de julio de 2000.

Ley 906 de 2004, de 31 de agosto, por la cual se expide el Código de Procedimiento Penal. Diario Oficial No 45.658, 1 de septiembre de 2004.

Ley 1142 de 2007, de 28 de junio, por medio de la cual se reforman parcialmente las Leyes 906 de 2004, 599 de 2000 y 600 de 2000 y se adoptan medidas para la prevención y represión de la actividad delictiva de especial impacto para la convivencia y seguridad ciudadana. Diario Oficial № 46.673, 28 de julio de 2007.

Ley 1453 de 2011, de 24 de junio, por medio de la cual se reforma el Código Penal, el CPP., el Código de Infancia y Adolescencia, las reglas sobre extinción de dominio y se dictan otras disposiciones en materia de seguridad. 24 de junio de 2011. Diario oficial № 48.110, 24 de junio de 2011. 
Ley 1760 de 2015, de 6 de julio, por medio de la cual se modifica parcialmente la Ley 906 de 2004 en relación con las medidas de aseguramiento privativas de la libertad.

Ley 1826 de 2017, de 12 de enero, por medio de la cual se establece un procedimiento penal especial abreviado y se regula la figura del acusador privado. Diario Oficial № 50.114, 12 de enero de 2017.

Ley 1908 de 2018, de 9 de julio, por medio de la cual se fortalecen la investigación y judicialización de organizaciones criminales, se adoptan medidas para su sujeción a la justicia y se dictan otras disposiciones. Diario Oficial No 50.649, 9 de julio de 2018.

\section{Normas Internacionales:}

Comisión Interamericana de derechos humanos (2013, 30 de diciembre): Informe sobre el uso de la prisión preventiva en las Américas. OEA/Ser.L/V/II. Doc.46/13.

Comisión Interamericana de derechos humanos (1997, 11 de marzo): Caso Bronstein y Otros Vs. Argentina. Informe № 2/97. Casos 11.205, 11.236, 11.238, 11.239, 11.242, 11.243, $11.244,11.247,11.24811 .249,11.251,11.254,11.255,11.257,11.258,11.261,11.263$ $11.305,11.320,11.326,11.330,11.499$, y 11.504. Argentina.

Comisión Interamericana de derechos humanos (2002, 27 de diciembre): Fondo Waldemar Gerónimo Pinheiro José Víctor Dos Santos Paraguay. Informe № 77/02. Caso 11.506

Comisión Interamericana de Derechos Humanos (2009, 6 de agosto), Fondo José, Jorge y Dante Peirano Basso. Informe No. 86/09, Caso 12.553.

Convención Americana sobre Derechos Humanos (1969, 7-22 de noviembre): (Pacto de San José). Suscrita en la conferencia especializada interamericana sobre derechos humanos (b32).

\section{Jurisprudencia citada}

Corte Constitucional de Colombia (1992): Sentencia T 571. M.P. Jaime Sanín Greifenstein. Corte Constitucional de Colombia (1994): Sentencia C 221. M.P. Carlos Gaviria Diaz. 
Corte Constitucional de Colombia (1996): Sentencia C 689. M.P. José Gregorio Hernández Galindo

Corte Constitucional de Colombia (1997): Sentencia C 327. M.P. Fabio Morón Díaz.

Corte Constitucional de Colombia (1997): Sentencia C 475. M.P. Eduardo Cifuentes Muñoz.

Corte Constitucional de Colombia (1998): Sentencia SU 747. M.P. Eduardo Cifuentes Muñoz.

Corte Constitucional de Colombia (2000): Sentencia C 634. M.P. Vladimiro Naranjo Mesa.

Corte Constitucional de Colombia (2001): Sentencia C 774. M.P. Rodrigo Escobar Gil.

Corte Constitucional de Colombia (2002): Sentencia C 805. M.P. Manuel José Cepeda Espinosa y otro.

Corte Constitucional de Colombia (2005): Sentencia C 1154. M.P. Manuel José Cepeda Espinosa.

Corte Constitucional de Colombia (2006): Sentencia C 456. M.P. Alfredo Beltrán Sierra.

Corte Constitucional de Colombia (2007): Sentencia C 176. M.P. Marco Gerardo Monroy Cabra.

Corte Constitucional de Colombia (2007): Sentencia C 396. M.P. Marco Gerardo Monroy Cabra.

Corte Constitucional de Colombia (2008): Sentencia C 318. M.P. Jaime Córdoba Triviño.

Corte Constitucional de Colombia (2008): Sentencia C 1198. M.P. Nilson Pinilla Pinilla.

Corte Constitucional de Colombia (2008): Sentencia T 760. M.P. Manuel José Cepeda Espinosa.

Corte Constitucional de Colombia (2011): Sentencia C 879. M.P. Humberto Sierra Porto.

Corte Constitucional de Colombia. (2012). Sentencia T 905. M.P. Jorge Ignacio Pretelt Chajub.

Corte Constitucional de Colombia (2012): Sentencia C 121. M.P. Luis Ernesto Vargas Silva.

Corte Constitucional de Colombia (2014): Sentencia T 196. M.P. Gabriel Eduardo Mendoza Martelo. 
Corte Constitucional de Colombia (2015): Sentencia C 144. M.P. Martha Victoria Sáchica Méndez

Corte Constitucional de Colombia (2016): Sentencia C 469. M.P. Luis Ernesto Vargas Silva.

Corte Constitucional de Colombia (2019): Sentencia C 588. M.P. José Fernando Reyes Cuartas.

Corte Interamericana de Derechos Humanos: Caso Chaparro Álvarez y Lapo Íñiguez vs. Ecuador. Sentencia. Excepciones preliminares. Fondo: reparaciones y costas, 21 de noviembre de 2007.

Corte Interamericana de Derechos Humanos: Caso Suárez Rosero Vs. Ecuador. Sentencia. (Fondo), 12 de noviembre de 1997.

Corte Interamericana de Derechos Humanos: Caso Norín Catrimán y otros (dirigentes, miembros y activista del pueblo indígena mapuche) vs. Chile. Sentencia. Fondo: reparaciones y costas, 29 de mayo de 2014. 